\title{
A Journey of Salvation and Redemption through Displacement: A Psychoanalytic Reading of J. M. Coetzee's Age of Iron.
}

\author{
Dr. Mohamed Fathi Helaly Khalaf
} Assistant Professor, College of Arts and Science,

Prince Sattam Bin Abdulaziz University, KSA. 



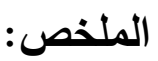

رحلة الفداء والعتق عبر الازاحة قراءة التحليل النفسى فى رواية عصر الحديد آليات الدفاع هى وسائل يلجأ اليها الاسوياء من الناس من اجل تجنب القلق الناشئ عن بعض المشاعر السلبية تجاه موقف او شخص ما تعد اللزاحة احد اكثر آليات الدفاع الثائعة التى تعمل لا اراديا فى العقل وتقوم بتحويل المشاعر السلبية تجاه هذف ما الى مشاعر مقبولة فى هذه الراوية يتبع جى ام كوتزى منهج التحليل النفسى فى رسم شخصية اليزابيث كارن لا براز سخطه الثخصى تجاه نظام التمبيز العنصرى السائد فى جنوب افريقيا متخدا فى ذللك آلية الدفاع الازاحة كوسيلة للتكيف مع الموقف الذى وجدت نفسها فيه اليزابيث كارن سيدة بيضاء ترفض التمييز العنصرى وممارساته القمعيه وتتخذ من الكتابه لابنتها الغائبة وسيلة للتعبير عن رفضها لهذا النظام الحاكم فى ذللك تمثل علاقتها مع من حولها من السود الذين يعيشون المادة لهذا الخطاب الاعترافى حيث تقوم بازاحة مشاعرها السلبية تجاه النظام الحاكم كوسبلة للتكيف مع موقفها كعضو ينتمنى الى الجنس الابيض رافضة لهذا النظام فى محاولة منها لاايجاد معنى لحياتها.. 


\section{Abstract:}

Defense mechanisms are coping techniques that people unconsciously employ to avoid the tension arising toward a certain situation, person, idea or any object. Displacement is one common defense mechanism that unconsciously operates in the mind to turn the negative feelings toward a certain target to acceptable ones. J.M.Coetzee adopts the psychoanalytical approach in portraying the character of Elizabeth Curren to convey his own contempt toward Apartheid in South Africa taking Displacement as a means of coexistence with the situation in which she finds herself. Coetzee gives an example of a white character who is not in line with the oppressive Apartheid. Because of her inability to openly express her negative feelings toward the regime, she finds in writing a letter to her daughter a means to adapt to her situation. In doing so, she finds in her relationship with the Blacks in her community the substance of her confessional writing. In a word, the present study aims to underscore the importance of defense mechanisms as coping techniques to make their life meaningful.

Keywords: Apartheid, oppressive, defense mechanism, adapt, connect with, confessional, unacceptable, unlovable, coping, psychoanalysis. 
The present study aims at investigating the psychological pressures that result from suppression of the individual feelings toward one object or another and his/her attempt to find a way to overcome such feelings. The main objective of the study lies in exploring the Psychoanalytic approach of J.M. Coetzee in Age of Iron and his vision of the dilemma of both the oppressed and the oppressor to come to terms with the situation in which they find themselves under Apartheid in South Africa. It examines how Elizabeth Curren (white South African) finds in Displacement, as a defense mechanism, a means to project her contempt toward the ruling regime through an act of confessional writing to her daughter who lives abroad at one level. At another level, Mrs. Currens endeavor to terms with her situation through connecting with some black people in her community is of a primary concern in this study. In a word, Displacement as a defense mechanism is carefully examined throughout all the attempts of the protagonist to adapt to her situation to make her life meaningful in some way.

One's choice of J.M. Coetzee for critical appraisal is largely informed by his unique status in African literature as a Nobel Prize winner and his status as a white writer of mixed origins as well as my personal fascination with how his works are didactic and very illuminating. Taking into account the works reviewed above with certain unavoidable limitations, it is clear that Coetzee's Age of Iron was looked upon from different perspectives and little attention has been given to fully examining it from a psychoanalytic point of view. The purpose of the present study is to psychoanalytically analyze Age of Iron from this standpoint. It will examine how Coetzee has employed this approach to convey the theme of an ethical journey of survival in the subject novel.

Age of Iron deals with the sufferings of a white woman as a result of her inability to express her feelings of resentment toward the regime in South Africa under Apartheid and her attempt to find meaning for her life. Therefore, the present study will be conducted from a Psychoanalytic standpoint. Hence, the Psychoanalytic approach to literature will be employed as it entails 
examining human conducts as a means of enlightening people of the reality of their behavior taking literature as a medium of instruction for the sake of improving relationships among people in any given society. Coetzee's Age of Iron is examined as an indictment of the South African society on account of oppressing both its black citizens because of their color of skin and some of its white citizens through not allowing them to express to express their indignation toward its oppressive practices. Here, the researcher will present the difficulties that Mrs Curren has to undergo to find a means to adapt to her situation. She finds in Displacement a way-out for her suppressed feeling toward Apartheid

That's my first word, my first confession... I want to be saved. How shall I be saved? By doing what I don't want to do.... I must love, first of all, the unlovable. (Coetzee. 1989 124)

Every human being has his own emotions that vary from one emotion to another according to his/her attitude toward a certain object, person or idea. Such emotions can be either negative or positive. Negative emotions are sometimes indirectly reflected on another person, object or idea other than the original to avoid negative consequences. When a person fails in facing a certain problem, he/she tries to find some way to adapt himself/herself to reduce the tension arising from his/her inability to openly face that problem. A human soul generally seeks to get happiness and to avoid pain. One way to get that happiness and avoid pain is to shift his/her negative feeling onto another target. In psychology, this process is known as a defense mechanism. What is a defense mechanism? A defense mechanism can be defined as an unconscious process that a human being uses to avoid or reduce the tension that arises from a situation that he/she sees as unpleasant or unacceptable in an attempt to make it pleasant or acceptable in some way. A defense mechanism is a coping strategy that is unconsciously employed by people to come to terms with the unpleasant situations in their everyday life. (McLeod 2017 5)

In order to deal with conflict and problems in life, Freud stated that the Ego employs a range of defense mechanisms. Defense mechanisms are psychological strategies that are unconsciously used 
to protect a person from anxiety arising from unacceptable thoughts or feelings. We use defense mechanisms to protect ourselves from anxiety or feeling of guilt that comes out when we feel threatened. (Freud 1937 12) According to psychoanalysis, a Defense mechanism is a mental process that enables the mind to reach compromise solutions to conflicts that it is unable to resolve. The process is usually unconscious, and the compromise generally involves concealing from oneself internal drives or feelings that threaten to lower self-esteem or provoke anxiety. (Encyclopedia Britannica)

Displacement is one common mechanism used by people to adapt to certain situations. It occurs when a person finds himself/herself in a situation that he/she does not like and feels unable either to accept or reject. Toward such a situation he/she shifts his/her negative attitude, feeling or emotion to another object or person that he sees as less threatening, less unpleasant or less harmful than the source in order to avoid negative consequences. In other clearer words, Displacement is a defense mechanism that operates unconsciously in the mind. It involves emotions, wishes or ideas that are transferred from the original source of tension to a more acceptable substitute in a way that gives the person some mental peace. According to Freudian psychoanalysis theory, Displacement comes about when a person shifts his/her impulses from an unacceptable target to an acceptable one. In a word, in Freudian psychology "Displacement is an unconscious defense mechanism whereby the mind substitutes either a new aim or a new object for goals felt in their original form to be dangerous or unacceptable." (Psychology. Wikipedia)

Again, according to Freud, Displacement means unconsciously taking one hostile or angry emotion from one situation onto another. It is a process of unconscious shifting of our negative emotion to another less threatening target. It occurs when one feels like reacting to a certain unpleasant situation but he/she knows that he can't directly react because of certain reasons. Examples of situations in which people resort to Displacement as a means to redirect their negative feeling toward another person or object that he/she sees as 
less threatening. In doing so, he/she unconsciously tries to get rid of such negative feelings.

South Africa has suffered from long years of oppression, violence and discrimination under the ruling system of Apartheid. It (Apartheid) has had an overwhelming impact on the society of South Africa especially on the Blacks. This has created a state of disharmony between the people and the ruling regime. Apartheid has also had its impact on both the oppressed and the oppressor. Black South Africans are oppressed at many levels. The young generations are shaped by oppression and insecurity. They try to find a way out to reflect their suppressed feelings of fear and insecurity. Under Apartheid, all the bodies of the ruling regime, especially the body of the media, are directed toward serving the regime in many ways. Mass media are not transmitting the reality of the kind of life led by the Blacks. As the story tells "The Radio says nothing, the Television says nothing, the newspapers say nothing of the events in the black township." (Coetzee 1989 11)

Furthermore, the ruling regime takes measures to present an image of a stable society in which all the young people (black and white) of the country are happily living their life together. However, it is a society where black people are oppressed and demeaned to a degraded status. Blacks are denied their civil rights. They do not enjoy the least freedom of expression in mass media. Poverty is widespread in black districts. On the other hand, the places where the white live reflect the kind of comfortable and luxurious lives they are leading. The society is divided in two completely different sets in terms of the power and resources available to each. It is in such racial and ethnic communities that one can see those who possess everything and those who possess nothing, those who are powerful and those who are powerless.

J. M. Coetzee is a South African writer of hybrid origin. He has both English and African ancestors. His position as a writer in South Africa is very critical. He has lived in a period in which the majority of Blacks are oppressed at the hands the white regime. Coetzee's novels are particularly important for their political significance. In his novels, Coetzee declares his attitude toward the past history of 
Apartheid. His stance against the situation in South Africa can be clearly seen in his different novels. He states "I regard it as a badge of honor to have had a book banned in South Africa, and even more of an honor to have been acted against punitively." (Coetzee. 1992 51) He even identifies himself with the problems of the oppressed in his society. Coetzee's novels represent element of resistance, protest and violence. In his novels, one can find vivid description of a society torn between different forces of oppression, violence, oppression and subjugation. People are not equal under the same regime. They feel insecure, disappointed and even losing hopes of a better future. In this regard, David Attwell contends "Coetzee's novels constitute a psychological allegory in which the narrators struggle to represent themselves in traditional South Africa literary discourse." (Attwell.1990 59)

Age of Iron is a novel that is mainly concerned with the impact of Apartheid on the psyche of both the oppressed and the oppressor in South Africa. Age of Iron is directly linked to a particular historical period in South Africa. It is a vivid depiction of the injustice and deterioration of life of the Blacks under the ruling regime. It also depicts a period marked by a struggle for liberation. It marks a shift of emphasis from the suffering of the Blacks as told from the perspective the Blacks to the same from the perspective of the Whites under the same ruling system.

Age of Iron is written in the form of a letter by a mother to her daughter. It is written from the perspective of a white woman who is not in line with Apartheid so as to recover from a feeling of complicity with the ruling system. The daughter has left for USA as a result of her contempt toward the deterioration of the political situation in South Africa. She is not willing to come back to South Africa. From the story, it can be understood that she has had a bad experience in South Africa. Unlike the mother, the daughter must have had more interface with the outside community and, in turn, must be more aware of the reality of what has happened around her as a result of mingling with other children. Living alone after the immigration of her daughter, Mrs. Elizabeth Curren (the protagonist) goes to relate 
the events of her life after being informed of her terminal cancer in the form of a letter. She takes writing as a private means to demonstrate her love for her daughter as well as a means to show her contempt toward the ruling regime. The letter serves as a testimony to her suffering as well as the suffering of the blacks to whom she connects. Primarily, Elizabeth Curren lives in her house unaware of the reality of the deteriorating situation in the society of South Africa. All that she knows about the outer society is confined to what she sees and hears on the radio and television. Violence and oppression are widespread in Cape Town and other places around South Africa. She herself is against such practices. She goes to describe the dark history of white oppression saying "A crime was committed long ago. How long ago? I don't know. But longer than 1916. So long that I was born into it. It is part of my inheritance. It is part of me. I am part of it. (Coetzee. 1989 164)

In writing to her daughter, Curren finds a way to absolve her sense of guilt and shame. She endeavors to make her voice publically heard. She sees Apartheid as suppressing people for too long without listening to their needs, and the result is deterioration in the society as a whole. It is like a sick person who refuses to obey his doctor's advice and the result is deteriorating health condition." (Hasselquist 2011 17) Mrs Curren expresses her distrust of Apartheid through showing contempt toward the ruling system as a whole. She states "Though colonialism was not a crime I asked to be committed, it was in my name." (Coetzee. 1989 149) Mrs. Curren comes to the realization that writing a letter to her daughter is a compromise between her being white and her unspoken rejection of the oppressive practices of the regime. This compromise is demonstrated in the form of writing a letter. As James Poyner puts it "Curren's letter to her daughter can be seen as a conduit for getting her voice heard on what she sees as wanton violence both on the state and the black community levels; she wants to express her opinion from a liberal position." (Poyner. 2009 113)

Mrs. Curren hears about the fighting that is taking place in the neighborhood where the black young generations are in struggle against Apartheid. Mrs. Curren is the only white character in the novel 
who sympathizes with the Blacks. She is even unhappy with being born as white and she wishes she were not born as such. As Erik Grayson remarks

Elizabeth Curren eventually comes to sympathize with the plight of young revolutionaries when she makes the uncomfortable realization that the waning generation to which she belongs, encourages violent political actions to justify sending young men to do violent action and push them to death. (Grayson. 2010 29)

Elizabeth's conscience is troubled and she tries to find a way to comfort it through confession. She was not fully ignorant of what is going around her, and gradually, she starts to identify with the young black generation and their rejection of Apartheid and its practices. She develops gradual contempt toward the regime. She states "Is this how I feel about South Africa, not loving but habituated to its bad smell." (Coetzee. 1989 70) She starts to question the world she lives in.

It is through her contact with the people around her that Elizabeth starts to realize how the political situation in Cape Town is deteriorating. She is awakened by seeing and hearing about the oppressive practices of Apartheid and how such practices are received with violence by the young black generations in South Africa. In the beginning she blames the black children for their violent actions against the white police. However, her views starts to change once she becomes in a direct contact with them. Being surrounded by Blacks, and having developed cancer, Curren appears as psychologically oppressed by finding herself confined to life in Cape Town. In this due light, Grayson points out "Feeling herself trapped in a lonely place where no one is watching out for or willing to engage in discourse with her, Curren experiences a sense of fury at the devaluing of her life by those around her." (Grayson.2010 48) She has to find a way that enables her to psychologically survive. In other words, she has to find a way to find meaning for her existence. 
In writing to her daughter, Curren finds the only available means through which she can adjust herself to the situation in which she finds herself. She takes it as a means to maintain her existence and to give meaning to a life that she sees as worthless. It is also a means by which she can give authority to her marginalized voice. In other words, writing to her daughter is a way to defend herself and to keep her existence. She gives her writing legacy through communication with others. Yet, she develops a sense of shame out of her feeling that she is associated with the Apartheid system. She gradually realizes the brutality of the ruling regime and considers it as shameful. It touches her because she is still a white South African. "There is shame to this private knowledge ... There seems to be no limit to the shame a human being can feel" (Coetzee 1989 119) Hence, Curren goes to develop an attitude of empathy toward all those black characters that she has direct connection with.

Elizabeth Curren finds herself leading a kind of troubled and confused life as she cannot side with the regime nor oppose it. She finds in Displacement a way out for her unspoken misery. Being influenced by black suffering around her, she writes to her daughter about her inner feeling. In doing so, she goes to reveal her contempt toward the regime, on the one hand, and to love those Blacks she is connected with on the other. In brief, she finds salvation for her soul in loving them. It is through her relationships with the people around her that she also seeks redemption of her feeling of guilt. Such people can fill the gap left by her daughter. It is her care for both her daughter and the people she is connected with that leads her to assess the situation in which she finds herself.

Having seen and heard about the fighting taking place in the black neighborhood, Mrs. Curren starts to be aware of the reality of the plight of the black people living in her community. She goes to reveal her inner psychological feelings of ailment and physical feeling of pain through writing to her daughter. That is to say, Curren's letter to her daughter takes the confessional form in which she can freely express her indignation toward the political situation of the Blacks in a society where personal free expression is denied. She states: 
It is like being on trial for your life and being allowed only two words, Yes and No. Whenever you take a breath to speak out, you are warned by the judges: "Yes or No; no speeches." "Yes," you say. Yet, all the time you feel other words stirring inside you like life in the womb. (Coetzee 1989 132-33)

On the other hand, she realizes that to lead a comfortable life is largely dependent on connecting with others. She also realizes that being close to them is an acceptable (on her part) way for achieving some fulfillment on her own terms. In other clearer words, writing to her daughter is a way of adjusting to the situation she finds herself in through transferring her feeling of contempt and sense of guilt toward Apartheid in the form of a letter.

Generally, Mrs. Curren's suffering is great.as her physical suffering coincides with her psychological suffering. Her physical suffering is the result of her terminal cancer and her psychological suffering is a result of her feeling of complicity with Apartheid. She develops cancer and she thinks that her deteriorating health condition is an extension of the deteriorating political condition in South Africa. She states "I have a child inside me that I cannot give birth to, cannot because it will not be born, because it cannot live outside me. So it is my prisoner or I am its prisoner". (Coetzee 1989 82) She considers cancer and Apartheid as equal.

Mrs. Curren struggles to overcome her trouble through her connection with others around her. She is not at all happy with the brutal acts of Apartheid that she is unable to find the suitable words to express her contempt toward the same. Her contact with the outside world makes her fully aware of the great suffering of the Blacks under the oppressive ruling system. Hence, she finds a way of expressing her ethical vision faithfully through her relationships with others. It is through such people that she goes to fill the gap created by her daughter. In a word, Curren has sought redemption of her sense of guilt and salvation of her soul through these people and she succeeds in finding them. 
In her endeavor to care for the people around her, Curren is ultimately free. She has the freedom to either care for or ignore them. While living alone, Curren's life is invaded by a stranger named Vercueil. He is a derelict who appears in her life the day she knows about her illness. Initially, she shows some disgust toward his smell and his dirty appearance. Gradually, she starts to get familiarized with his existence in front of her house. She offers him food. She becomes aware of his needs and starts to assign certain tasks to him in return of giving him shelter. As the story unfolds, Curren realizes that she needs him and that his existence becomes indispensable to her. She grows closer to him. In her letter to her daughter, she states "Because I cannot trust Vercueil, I must trust him. I am trying to keep a soul alive in times not hospitable to the soul." (Coetzee 1989 130)

In her journey of salvation, Mrs. Curren finds her relationship with Vercueil an important one. She sees her present life as greatly connected to him. Despite his bad smell and his unhygienic look, she finds in him a means to come to terms with her illness after the departure of her daughter. That is to say, in her relationship with him, she finds a way to achieve some fulfillment in some way. She states:

That is my first word, my first confession. I do not want to die in this state I am, in a state of ugliness. I want to be saved. How shall I be saved? By doing what I want to ... That is the first step: that I know I must love first of all, the unlovable ... He is part of my salvation. I must love him. (Coetzee 1989 124-25)

Displacement works as an unconscious force in the mind of a person whose negative emotions toward a certain target turns to be acceptable. Curren's letter to her daughter is, again, a means through which she can adapt to her situation in South Africa. In the letter, she reveals how she feels toward the surrounding community. She says "This is never meant to be the story of a body, but the soul it houses." (Coetzee 1989 185) Curren appears as very kind toward Vercueil that she, as the story tells, tries to keep her soul "alive". In this due light, Pojanut Suthipinitharm points out: 
Vercueil through Curren's pen is a statement to her idealistic desire for outside politics and condensations that, almost her immediate reality, seem entirely inappropriate. She invests hope in him to release her from the shackles of her shameful state when she does not know how. (Suthipinithram 2015 88)

Both Curren and Vercueil develop some sort of understanding, and the former gets familiarized with the latter's smell and dirty look. Moreover, she goes to put great trust in him that she chooses him as the most trustworthy person to send her letters to her daughter after her death. She tells him how she considers her letters to her daughter as her only inheritance and the only thing she can give her. She says "Those private papers, private letters; they are my daughter's inheritance. They are all I can give her, all she will accept ... I don't want them opened by or read by anyone else." (Coetzee 1989 28)

Choosing Vercueil as a mediator between her and her daughter implies how she values her relationship with him. In the course of the novel, Curren's health deteriorates more and more and Vercueil appears to be the only person who extends a hand of help. She considers him as her soulmate. "Two souls, his and mine, twined together, ravished" (Coetzee 1989 130) She tells him stories about her life. She even goes to share him the removal of one of her breasts which is the most intimate details of her body. She feels excited to find him accompanying her in her journey in her old car. She is impressed by his attachment to her. She remarks "What won me in the end was the new attention he was paying me. He was like a boy in a state of excitement. I was his object. I was flattered." (Coetzee 1989 117) Both develop a kind of mutual sympathy toward one another. In this due light, Hilmar Heister points out "The distance Mrs. Curren kept in the beginning did not stop her from having intimation of the bond existing between them". (Heister 2014 144)

Curren's relationship with Vercueil goes beyond the limits of intimacy to awaken her to a sense of how she stands in the surrounding world. While complaining about how she has become 
distanced from her daughter describing her as "She is like iron" (Coetzee 1989 75), Vercueil responds saying "You are like iron too" (Coetzee 1989 75) Here, Vercueil's spontaneous response implies how he considers her as part of the oppressive system that she despises. Generally, moved by the remark, she responds saying "Something broke inside me when you said that." (Coetzee 1989 75) She is hit to the core by what he states. She realizes her implicit complicity with Apartheid without being fully aware of this. Here, Curren is even forced to realize how her implicit complicity with Apartheid has affected her more than she would admit. It is a moment of insight on her part. What breaks inside is her previous self-image. She starts to reveal her ambivalent feelings toward Vercueil. She writes to her daughter "I trust Vercueil because I don't trust him. I love him because I on't love him." (Coetzee 1989 131) Curren goes even further to express such ambivalence in her letter "Why do I write about him? Because he is and he is not. Because in the look he gives me I see myself in a way that can be written. When I write about him, I write about myself. Otherwise what would this writing be but a kind of moaning now?" (Coetzee 1989 9) She thinks that she has some moral obligations toward Vercueil that she has to fulfill. It is through such obligations that she can mitigate her sense of guilt not only toward Vercueil, but toward the rest of the Blacks in her community.

Vercueil accompanies Curren in her journey to the town of Guguletu upon a request the latter receives from her housekeeper Florence. Florence is informed that her son and his friend have been injured badly at the hand of the white police. Really, it is a moment of humiliation on the part of Curren. There, in Gugletu, Vercueil is backing her when she is compelled to spend the night under a bridge. He emerges as the only person caring for her. Curren finds in him a substitute of her daughter and, gradually, she develops some growing affection toward him. On the whole, in her relationship with Vercueil, Curren finds a means to express her unspoken feelings toward the surrounding world in an acceptable way. In a word, Vercueil becomes a subject of Displacement of Curren's unspoken feeling and attitude toward the world around her. 
Curren's awareness of the pathetic situation of the Blacks comes as a result of her confrontation with the reality of oppression. Of course, such confrontation strengthens her resolve against Apartheid. She takes a stance against the regime and its authority. Her conscience is troubled and she tries to comfort it through sympathizing with black characters who are connected with her. Mrs. Curren's primary contact with the reality of the world around her is through her housekeeper Florence. Florence supports black children to do some violence actions against the oppressive acts of the regime. Mrs. Curren is astonished of Florence' stance to the violent behavior of black children and her refusal to condemn it. Florence remarks "It is the White who made them so ....They are like iron". (Coetzee 1989 46) The remark made by Florence is just a start of changing Curren's attitude toward the surrounding community in which she lives. She starts to show great interest in what is going around her regarding the unrest associated with Apartheid. She is influenced by the violence wreaked upon the Black. Now she bcomes fully aware of the reality of the situation around her.

A considerable part of the story of Age of Iron takes place in a town called Guguletu. It is a town where great violence is committed against the Blacks. Florence, the housekeeper of Mrs. Curren's house, lives in Guguletu with her family. Florence once receives a call to go back to Guguletu to see what has happened to her son Behki and his friend John. Florence asks Mrs. Curren to accompany her in her journey to the township of Guguletu to show her the situation of the Blacks there. She comes face to face with the reality of the condition of the oppressive practices of the white police against the black children. There, she finds that Florence's son is killed at the hands of white police and John is badly wounded. Really, it is a moment of humiliation that affects her greatly. In her journey to Guguletu, Curren is shocked by the landscape on both sides of the road. As the story tells "Around us was a wilderness of gray sand .... Shreds of plastic, old iron, glass, animal bones littered at both sides of the path". (Coetzee 1989 93) 
Again, having seen how deteriorating the situation is in Guguletu, Mrs. Curren becomes increasingly aware of the reality of the world around her. Such growing awareness is accompanied by a similar connection with the poor blacks who live in her community. Though she has no hand in what is going around her, she develops a sense of guilt because of being white. This sense of guilt grows greater as a result of her confrontation with the reality of the situation around her. She realizes that for her own salvation, she has to recognize her guilt and connect with the souls of the oppressed. In this due light, William Purcell points out "She realizes that before seeking the forgiving of others, she has to forgive herself." (Purcell 2013 8)

Mrs. Curren becomes very involved in a new kind of life with the black living with her. Such involvement takes her from a life of seclusion in the neighborhood of Cape Town to a confrontation with the very reality of the black township of Guguletu. She realizes that the black young generations are in a continuous struggle against the practices of Apartheid. Thus, her trip to Guguletu marks a great turning point in her attitude toward Apartheid. In Guguletu, she knows about the murder of Florence's son (Bheki) and gets appalled at how he has been killed at the hands of the white police. She finds herself unable to find the suitable words to describe it. "To speak of it, you would need the tongue of a god." (Coetzee 1989 91) Seeing Bheki's dead body, again, induces in her a sense of complicity. She responds with shame. She decides not to close her eyes again. "Now my eyes are open and I can never close them again". (Coetzee 1989 94) Commenting on how shocking the situation in Guguletu is for her, and how she responds to it, Grayson points out "Elizabeth's reaction to her position is one of frustration and rage. She feels trapped in a lonely place where no one is watching out for or willing to engage in a discourse with her." (Grayson 2010 48)

Bheki and John have been pushed by a police van into another parking van. Both have been badly injured. Bheki has been admitted to a hospital because his wound is serious. Curren goes to the hospital to see him. Bheki dies shortly after her arrival and there, she sees how degrading the situation is for the Blacks inside hospitals. She states "This is the worst thing I have witnessed in my life." (Coetzee 1989 
103) She is left speechless on account of the incident. Here, again, she finds writing to her daughter as the only available way-out to reflect on her speechlessness. That's to say she finds in displacing her unspoken feeling of contempt onto writing a means to come to terms with the situation in which she is involved. She writes:

It is through my eyes that you see. The voice that speaks in your hand is mine ... I tell you the story not so that you will feel for me but so that you will learn how things are ... I am the only one. I am the one writing I, I. So I ask you: attend to the writing not to me." (Coetzee 1989 104)

Thus, Mrs. Curren's own enlightenment of her situation comes as a result of her confrontation with the reality of the oppressive Apartheid. Of course, this strengthens her resolve for salvation. As Hasselquist puts it "It is when Elizabeth Curren starts to question the world she lives in that she is awakened from her former drowsy state." (Hasselquist 2011 19) Being the only white person who develops such a negative attitude toward the practices of the ruling system, Curren appears as exhibiting a unique human approach represented in her connection with some black people and expressed in the form of writing a letter. She leads a life of getting the truth through questioning the reality of the surrounding community. She seeks salvation through demonstrating her ethical vision in the form of a confessional writing. It is through writing that she goes to express her love toward her daughter and to cast blame on Apartheid. That is to say, she finds in displacing her negative feeling of contempt in the form of writing a means of achieving salvation on her own way. Erik Grayson remarks "Mrs. Curren's letter to her daughter serves as a testament to her attempts to salvage meaning from her existence to preserve and extend her life beyond the grave." (Grayson 2010 30)

Bheki's friend, John, is another victim of Apartheid with whom Mrs. Curren also stays connected. He is a victim of oppression and exclusion at the hands of the state police. After John's recovery from the wounds as a result of being hit by a police car while accompanying Bheki, Mrs. Curren goes to advise John to abandon his 
involvement in the violent protest against the white police. Yet, he never follows her advice as he still sees her as one member of the white race. However, as the story unfolds, John leaves Guguletu and goes back to Cape Town to take shelter in Mrs. Curren's house. While being there, he is still chased by the white police. The police attacks Curren's house to catch him. He has a gun to defend himself. He keeps the gun inside Curren's house. She goes to protect him trying even to mislead the police. She is taken away by the police. She objects but her objection is received with indifference. She says "They paid my words no more attention than they would a child's" (Coetzee $1989155)$

Mrs. Cureen's sympathy with John constitutes a major part of her journey of salvation. Despite disregarding her advice of not joining the black militant groups in violence against white police, Curren develops sympathy toward John. She finds in protecting him, in her house from the white police, a means of expressing her rejection of the practices of Apartheid. She displaces her rejection of Apartheid through sympathizing with John. She sees him as a refugee that needs to be saved. She writes:

I don't love the child. in my heart I want him to go away and leave me alone. .... How shall I be saved? .... I must love, first of all, the unlovable. I must love, for instance, this child. He is part of my salvation. I must love him. But I don't love him. (Coetzee 1989 136)

Being moved by how John is targeted by the police, Elizabeth goes on protecting him. She has to love him as a way of absolving her conscience and redeeming her sense of complicity. Commenting on how Mrs. Curren's relationship with black children is an available means through which she has sought to find meaning for her life, PurMchael Marais remarks:

It is significant that Age of Iron should be a love story that deals with Mrs. Curren's recovery of her humanity after having been brutalized by the state's relations of power, a recovery which takes 
place only after she has learned to love the unlovable, namely the children of iron who have been metamorphosed by the deformed and stunted relations between human beings established by the state, she asserts her humanity. (Marais 2013 9)

Her love toward John is almost equal to her love toward her daughter. In other words, she finds salvation of her soul in loving him as an act of compensation. In this due light, Hilmar Heister remarks "Curren moves on to connect her capacity to love her daughter to her capacity to love this boy (John) not a scale with two sides to choose from, but rather a potential that can only be realized in application to both, and for all that matters, to anyone and everyone." (Heister 2010 152)

Generally, in her journey of salvation, Curren sees that her deteriorating health condition symbolizes the deteriorating political condition of the South African society. That is the oppressive practices of Apartheid result in deterioration both at the individual as well as the community levels. Jan Kosecki points out "The disintegration of the body in disease seems as a consequence of years of moral corruption where moral corruption is structured as ugliness." (Kosecki 2012 23) Curren has become fully aware of the impact of Apartheid and how she is, implicitly, an accomplice with it. She imagines walking upon black faces of dead black bodies. She says: "When I walk upon this land, I have a gathering feeling of walking upon black faces. They are dead but their spirits have not left them. They lie there obdurate, wanting for my feet to pass, waiting for me to go, wanting to be raised up again." (Coetzee 1989 125)

As the story closes, Mrs. Curren persists in her attempt to, finally, find a way to express her resentment toward the regime. She has already taken a stance against Apartheid through siding with blacks. After coming back from Guguletu, Curren develops a desire to commit suicide. She goes to share Vercueil, for the first time, a bottle of liquor. She wants to set herself on fire in protest against the regime. She has already lost faith in everything around her. She sees suicide as the least available means for the salvation of her soul. It is the last part of her journey of salvation. "Death by fire is the only death left-to- 
burn and be-gone, to be rid of, to love the world clean." (Coetzee 1989 165) Commenting on Curren's desire to commit suicide, Jan Kosecki remarks "Curren's act of suicide can be seen as an act of alterity with the self. Death through suicide is an act of atonement." (Kosecki 2012 41) Again, her attempt to commit suicide is an act of redirecting her rejection of Apartheid toward getting rid of her own life. In other words, because of her inability to openly express her opposition to the regime as a whole, she thinks of suicide as the only possible way to overcome her personal plight. Of course, Curren's opposition to the regime is highly appreciated by all the concerned onlookers. She has tried hard to get of that sense of complicity but she fails because of her inability to freely express her opposition. Displacement as a defense mechanism can reduce the tension emanating from suppression but not on a permanent basis. Also, her attempt of suicide as the only means is not welcomed because she will die suppressed. She can gather people of the same attitude around her to strengthen their resolve in coming to terms with the situation in which they find themselves.

To conclude, Displacement is a defense mechanism that unconsciously, operates in the human minds. It is a mechanism that a human being unconsciously resorts to adjust to a certain situation by means of directing his negative emotions toward a certain object other than the original to make them acceptable in some way. In his portrayal of the character of Elizabeth Curren, Coetzee has adopted the psychoanalytic approach to underscore how she finds in Displacement a way to defend herself and to adapt to the situation in which she is cast. She finds in connecting with other blacks a means of changing her negative feeling of contempt toward Apartheid to some acceptable feelings of care and love in a confessional letter. Mrs. Curren chose to write to her daughter to freely express her feelings of contempt toward Apartheid simply because she can neither oppose nor face the consequences of openly facing the system. She sees writing as less threatening and less harmful. In doing so, she could gain some form of mental peace by directing her negative emotion to another object. 
On the whole, Elizabeth Curren's health condition combined with the situation in which she is involved as well as her act of writing can be seen as a way to defend herself in an acceptable manner. It has sought a means to absolve her inner feeling of resentment toward the regime and she could succeed in finding one. Really, it is an act of displacement. She could achieve salvation of her soul through an act of confessional writing. Connecting with others around her has constituted the substance of her confession. She has found in developing some feeling of empathy toward those around her a means for the salvation of her soul and redemption of her feeling of complicity. In a word, she has taken Displacement as a coping technique to defend herself and to create a meaning for her existence. 


\section{Bibliography:}

Attwell, David. 1990. The Problem of History in the Fiction of J.M.

Coetzee. Poetics Today. Vol. II. No. 3

Coetzee, J.M. 1992. Doubling The Point: Essays and Interviews. Cambridge Harvard Uni. Press.

Coetzee, J. M.1990. Age of Iron. London, Michelin House.

Freud, A. 1936. The Ego and the mechanisms of defense, London: Hogarth Press and Institute of Psycho-Analysis

Grayson, Erik 2010. "The Ones Who Cry": Aging and The Anxiety of Finitude in J.M. Coetzee's Novels of Senescence. An Unpublished $\mathrm{PhD}$ thesis. Binghamton University. New York.

McLeod, S. A. 2017. Defense mechanisms. Retrieved from https://www.simplypsychology.org/defense-mechanisms.html

Hasselquist, Henrik 2011. Decay and Downfall in J.M. Coetzee's Age of Iron, School of Languages and Literature.

Heister, Hilmar 2015. The Sympathetic Imagination in The Novel of J.M. Coetzee. A PhD thesis. Humblot. University of Berlin.

Kosecki, Jan 2012. Metaphors of The Body in the Fiction of J.M. Coetzee. PhD Thesis. University of London. Royal Holloway.

McLeod, S. A. 2017. Defense mechanisms. Retrieved from https://www.simplypsychology.org/defense-mechanisms.html

Mahmoud, Jihan 2014. Deconstruction of Different Forms of Apartheid in The Works of Edward Said, J.M. Coetzee and Jabra Ibrahim Jabra: A Comparative Study of Violence, Resistance and Alienation. A PhD thesis, Cardiff University.

Marais, ParMichael.2013. J.M. Coetzee's Age of Iron and The Role of Literature in South African Society. Cahiers Forell - Formeset Representation Linguistigue et Litterature. 
Moosa, Mitha, Mehmoona 2015. The Age of Iron, J.M. Coetzee and The Ethics of Encounter with the Other A Levinasion Analysis, University of Victoria, Researchgate.

Poyner, James 2009. J.M. Coetzee and The Paradox of Postcolonial Authorship. Writing in The Face of Death in The Age of Iron.

University of Exeter. UK.

Purcell, William 2013. How Shall I be Saved? The Salvation of Mrs. Curren in Coetzee's Age of Iron, Transitional Literature. Vol. 6 No. I.

Smuts, Eckerd 2017. J.M. Coetzee's Age of Iron and The Poetics of Resistance. The Journal of Commonwealth Literature. Vol. 52. No. 1.

Suthipinithram, Pojanut 2015. My Truth: How I Lived in These Times, in The Place: Reading The Body-Soul in J.M. Coetzee's Late Fiction. A PhD thesis, University of New York.

Thornton, Lawrence 1990. Apartheid Last Vicious Gasps. Books Review Desk Vol. I Late Edition, Final Section. 
Web sources

(Psychology. Wikipedia)

https://www.britannica.com/topic/defense-mechanism

https://www.alleydog.com/glossary/definition-:displacement

https://www.simplypsychology.org/defense-mecha;nisms.html 